\title{
Christopher Benjamin's Eco-Innovators: Sustainability in Atlantic Canada: stories to change minds and move hearts
}

Tami Ambury*

MacEwan University, Canada

\begin{abstract}
In his 2011 book, Eco-Innovators: Sustainability in Atlantic Canada, environmental journalist Chris Benjamin provides a new kind of roadmap to a more sustainable future. In this work, Chris masterfully weaves the stories of 35 creative and dedicated individuals from the four Maritime Provinces who recognize the need to take action now. From more sustainable food, transportation, or housing choices, to new business models, to communitybased social marketing and branding, to journalists and educators raising their voices for change, Chris outlines some of the many narratives for change. In so doing, he offers workable options that inspire pro-environment attitude and behaviour change, at the individual, organizational, and systemic levels.
\end{abstract}

\section{Introduction}

Many Canadians are actively engaged in efforts to create a more sustainable future. Some remain relatively hidden from view, their ideas and behaviours potentially lost to 
others because they are regular individuals, though doing extraordinary things. One book that tries to shine a spotlight on these individuals, while simultaneously providing readers with a simple roadmap for this future, is journalist Chris Benjamin's Eco-Innovators: Sustainability in Atlantic Canada. This book is important because Chris shares stories highlighting the inventiveness and dedication of Canadians who recognize the need to take action now. Through an examination of Eco-Innovators, this paper hopes to outline some of the key methods by which we can work towards sustainability in Canada as a whole: building sustainable communities, establishing new business models, re-branding the environment, and supporting voices of change.

\section{Chris Benjamin: Environmental Journalist}

Chris Benjamin did not start out thinking he would be a journalist; he kind of stumbled upon the career (Interview, June 19, 2013). When a volunteer position came up at the student newspaper, the Dalhousie Gazette at Dalhousie University in Halifax, he jumped at the opportunity, and chose to write about things he wished they addressed in his Bachelor of Commerce program - sustainability, social justice, social good and the like. During our interview, Chris said, "When I was in business school, it was extremely conservative. I was really an outlier, in my point-of-view. People made fun of my columns a lot, in a nice, friendly way, but still...”(Interview). Upon completing a Masters of Environmental Studies at York University in Toronto, Chris worked in the environmental field in Toronto, first with Greenest City and then the Toronto Region Conservation Authority. He also freelanced, writing about the environmental work he was doing.

In 2006, Chris took a position as a journalist in Ghana, West Africa, at the daily national paper, The Statesman. Once there, he covered stories related to national development, "anything from health care to the environment to prison systems, human rights issues... eco-tourism (Interview)." After a six-month stint in Ghana, Chris and his wife returned to Halifax in 2008. Shortly thereafter, Chris, while continuing to work as a freelancer, was hired by The Coast, the local independent paper, to write an environmental column. In addition to his work on the environment, Chris published his debut novel, Drive-by Saviours, in 2010, longlisted for Canada Reads in 2011, the very year Nimbus Publishing put out Chris's Eco-Innovators: Sustainability in Atlantic Canada.

Examining Chris's resume, you get a strong sense of the breadth and depth of his writing experience - covering subjects from wind power to branding the environment, carbon taxes to cycling, and urban farming to Green Santa. His passion for both the 
environment and journalism are clear, as his desire to rally voices for real and sustainable change.

\section{Eco-Innovators and a More Sustainable Future}

The seeds for this project were first planted when Halifax-based Nimbus Publishing, the largest English-language publishing company east of Ontario, wanted to add an environmental book to their catalogue (Interview). Nimbus knew of Chris's writing from The Coast and approached him to join them in this project. The publishers originally wanted Chris to write a guidebook to environmental products in Atlantic Canada, a book in the same vein as Ecoholic: Your Guide to the Most Environmentally Friendly Information, Products and Services in Canada by Adria Vasil out of Toronto. Rather than produce a straightforward descriptive guidebook covering various categories - such as personal hygiene, clothing, food, home improvement, outdoor living, transportation, and more - Chris pitched a more personal narrative-focused version of the Atlantic Canada environmental tale. He felt that a series of narratives on Atlantic Canadians actively involved in a variety of sustainable choices would help inspire and motivate change in others. As Chris, in his introduction, writes so eloquently:

Stories, if we believe them, are humanity's most powerful tool. They determine how we understand and experience the world, and how we act within it. If our stories are of war then we war. If our stories are of control and dominion then we conquer and subdue. If our stories are of cooperation, hard work, and change then we adapt and persevere together. (Benjamin, 2011, p. 1)

While Chris acknowledges the complexity of the issues we face, noting specifically the challenges of "food scarcity, declining accessibility of cheap oil, climate chaos, the poisoning of our land, water and air" (p. 2), he is not ready to throw up his hands in despair Unlike others who either pretend climate change isn't happening while consuming without care or those who think the situation is beyond their ability to control, Chris sketches 35 stories of Atlantic Canadians that demonstrate and model a third way - the possibility of a move to a more sustainable lifestyle, through sustainable choices in housing, transportation, food, clothing, lawn care, vacationing and the like.

\section{Healthy Communities}

Housing brings environmental challenges of various kinds. Urban high rises, for instance, are heavily dependent on fossil fuels. Over six stories high, such buildings cannot be fueled by alternative energy sources such as solar panels (p. 29). Rural living, 
too, comes with its own challenges. Unlikely to be public transit accessible, rural homes leave people car-dependent, while suburbs are the worst of both worlds, necessitating the paving of paradise and spreading out our ecological impact. As Chris sees it:

Healthy neighbourhoods are those with good soil quality, minimal noise and vehicle traffic, clean air, plentiful sidewalks, ample green spaces and playgrounds, trees, quality housing, and opportunities for outdoor social gatherings. They minimize automobile use, social isolation, air pollution, noise, traffic fatalities, obesity, and water pollution from parking-lot runoff. (p. 32)

In terms of sustainable housing, Chris offers up two alternatives - straw bale homes and retrofitted existing structures. The first option, as illustrated in Eco-Innovators by Kim Thompson's Straw Bale Project in Nova Scotia, uses straw, as local, renewable, and extraordinarily inexpensive building materials. For her own home, Kim paid but $\$ 400$ for the straw bales essential to construct a two-floor dwelling (p. 27).

One other option is perhaps more appealing: quoting Carl Elefante, Chris writes "the greenest building is the one already built" (p. 34) because of the embodied energy already put into its "extraction, processing, manufacture, and shipping of materials" ( $\mathrm{p}$. 34). He recognizes, however, that work may be necessary to retrofit, reinsulate, and upgrade such a homes, and that toxic substances including asbestos may need to be removed.

Eco-Innovators also focuses on another aspect of sustainable housing, one that has little to do with the "green-ness" of the building itself. A 2011 study by the US Environmental Protection Agency, found that when you account for transportation energy, the most energy efficient home is one located within two kilometres of a public transit stop. In other words, "the home's location relative to transportation choices has a large impact on energy consumption," larger than any green features of the home itself (p. 108).

But what if public transportation is not available? Chris explores other lower impact forms of transportation: from the Grand Concourse walking trails of St. John's, Newfoundland, to the Bicycle Bus program in Summerside, PEI, to the CarShare program in Halifax. Perhaps the most creative of these is Prince Edward Islander Harry Smith's wind-powered Toyota RAV4, a vehicle purchased off eBay (p. 108). Feeling rather guilty about living in a large home off the transit line, Harry wanted to lessen his environmental impact. He felt plugging his car into the electricity grid was essentially the same as driving a gas-engine vehicle. To solve this dilemma, Harry purchased a wind 
turbine to fuel his new car (p. 110). While he recognizes that his transportation choice isn't going to "save the world... he's too stubborn to watch civilization crumble without at least showing people what else is possible" (p. 111). Though perhaps an extreme example, Harry's ingenuity can serve to inspire others to find solutions to their own environmental concerns.

Believing a "resilient community is one that isn't dependent on others for survival" (p. 8), Chris looks mainly to local solutions to make self-sustainability more attainable. With food, for instance, Chris points out that the vast majority of foodstuffs in Canada are products of a large industrialized food system "marinated in oil" (p. 80), travelling in some cases up to 8,000 kilometers from farm to factory to plate. As a direct consequence, he sees that much of our food dollar - 87 cents on the dollar in Nova Scotia - goes toward food giants like Cargill, Tyson and XL Foods (p. 82). By comparison, farmers in the Atlantic Provinces earn on average between $\$ 5,500$ and $\$ 12,000$ per year, a barely livable wage that, understandably, has left many farmers and their families with little choice but to sell their land to real estate developers and factory farm operators (p. 85).

This loss of local control over the food supply, however, leads to the very real danger that future disruptions, diversions, and price increases of imported foodstuffs will leave us without the ability to feed ourselves. Eco-Innovators posits several alternative options in this return to local fare. Tom Van Milligen's Swedish-style, small-scale hog farm and David Ling's mixed organic Fair Acre Farms provide models of successful family farms. To provide Halifax and area growers a space to sell their goods, Sean Gallagher opened Local Source grocery, "selling only local seasonal fruits and veggies, free-range meats, cheeses, and home-style cooking and baking" (p. 93). And Speerville Flour Mill in New Brunswick mills 145 different products, all organic and local where available (p. 88). In other words, no shortage of options exists for local fare, if a consumer is willing and able to search out more sustainable alternatives.

\section{Sustainable Business Models}

Eco-Innovators points to a number of new and more sustainable business models at opposite ends of the spectrum - the first represented here is a micro-business model proffered by Maggy Burns and the second, a green-growth model represented by Olivier Soaps. Burns, an activist and environmental worker by day, is also an entrepreneur turning other people's cast-off books into beautiful, upcycled journals - ReCover Journals - effectively saving junk from the landfill. Every season, retailers ask Burns if she has any new products for them (p. 19). While Burns did develop a few spin-off 
products under pressure from her distributors to stimulate demand for more stuff, ultimately she rejected this business model. "Maggy sees a strong connection between the typical growth-oriented business model and the destruction of the natural world (p. 19). It is not that she doesn't want to make money. She simply wants to do so while retaining her own ideas for sustainability.

The truth is, however, that most individuals, and certainly most businesses in capitalist societies, are not yet ready to buy into this micro-business model. As Marion Copleston of the PEI Environmental Health Co-op indicates, buying less or second hand is an adjustment for most consumers, "It's a battle because we've been trained to consume," she says, "and our economy depends on consumption, our politicians are lobbied by companies that need consumption" (p. 54). Chris, himself, found this type of drive during his days at Dalhousie, saying the following:

This is something I remember wrestling with in business school, this growth model that seemed just completely cancerous, because it was never questioned. In fact, there had to be annual growth. There always had to be annual positive growth in any business, without any inkling that that meant a negative impact on the ecosystem. (Interview, 2013)

What if, however, there was the possibility that growth could lead to the realization of our environmental goals? Chris sees this possibility in Olivier Soaps, a Ste-Anne-deKent, New Brunswick business, creating 300,000 bars of handcrafted soap per year (p. 55). At present, Olivier Soaps sells approximately 140 products. In order to reduce packaging concerns, most of the company's bar soap is sold package-less where possible; however, Olivier is "currently working with Nova Scotia suppliers to develop biodegradable plastics" (p. 57). To date, Olivier Soaps has been so successful they have opened 14 retail shops and manufacturing facilities in Toronto, Ottawa, and La Baie, Quebec (p. 57). "They have bucked yet another trend" says Chris, "with such a decentralized operation, but Pierre says it saves shipping, fuel, and emissions to keep their factories close to their stores" (p. 59). Vice President, Pierre Pelletier, recognizes that he has bought into the growth model but sees this as the path to environmental survival. Pierre sees the need to "grow to green the supply chain" (p. 59), and Chris concurs, stating the following:

The bigger they are, the more people they employ, the more people they represent, the more power they have to dictate how ingredients are grown, packaged, and shipped. Then they can impose Olivier's methods and philosophy, its respect for the environment, on others. (p. 59) 
In other words, if they buy into the traditional growth model with a twist, Olivier Soaps becomes a power player. They can then begin to set industry standards.

Chris sees hope in these different business models. During our interview, he stated:

To me, even though they're different - different world views, different business models - they all can have a positive impact ... what it boils down to is the mindset of the people running the place and if they have a strong, internalized environmental ethic, then that tends to play out in a truly green business and not a PR exercise.

So, perhaps one key element in the progression of the environmental movement is the education of a new entrepreneurial elite ingrained with this ethic.

This change in educational philosophy is, in fact, what is already happening around the world. Already some 514 business schools worldwide - 16 in Canada, including MacEwan University, University of Calgary, Simon Fraser University, York University, Concordia University - have signaled their agreement with this assessment by signing on as Principles for Responsible Management Education (PRME) members. The PRME are "a timely global call for business schools and universities worldwide to gradually adapt their curricula, research, teaching methodologies and institutional strategies to the new business challenges and opportunities" (PRME, 2013, para. 3) by integrating principles of corporate responsibility and sustainability.

In both our interview and in Eco-Innovators, Chris outlines progress in business education options along the same lines as PRME. In our interview, for instance, he pointed to the NGO Management stream in the Masters in Environmental Studies program at York University. This program attracts "very holistically-minded, sustainability-minded people who [are] very good at organizational stuff, the very skills you learn in business school" (Interview). While his environmental concerns may have made him an outlier in Commerce at Dalhousie during his BA days, the Faculty of Management at Chris's alma mater has since established a successful sustainability program, including a Centre for Sustainability. In Eco-Innovators, Chris further identifies the Environmental and Sustainability Studies program at Acadia University, focusing on hands-on experience for students both in the community. "Given that these are realworld experiences," says Chris, "they quickly learn about roadblocks - all the barriers and excuses people throw in the way whenever we try to make change" (pp. 188-189). A community engagement course in their final year of study challenges students to come 
up with their own community-based initiative (p. 189), providing them with yet more experience to take into their careers after university.

\section{Re-Branding the Environment}

Environmentalists have much to learn from business, particularly with regards branding and marketing. In his article "Branding the Environment" in The Coast from January 28, 2010, Chris identifies the crux of the problem for the environmental brand:

In the fight for those hearts and minds, the eco-freaks are up against capitalism's finest and most financed, the captains of industrial marketing, the manufacturers of cool. Environmentalists have countered with big ideas and righteous souls---and are decidedly uncool. (para. 2)

The environmentalist movement, says Chris, "tends to be seen as flaky and abstract. David Suzuki is one of our most famous members .... and he can never compare to Justin Bieber. There's just no rock star version of the environmentalist and that is ultimately a branding exercise..." (Interview, 2013). A Google trend analysis certainly supports this argument, with David Suzuki almost non-existent in both infographics below. Al Gore faired considerably better after An Inconvenient Truth was released in May of 2006, but his star seems to have waned, while that of the ultimate capitalist, Donald Trump, pulled a branding coup with The Apprentice.

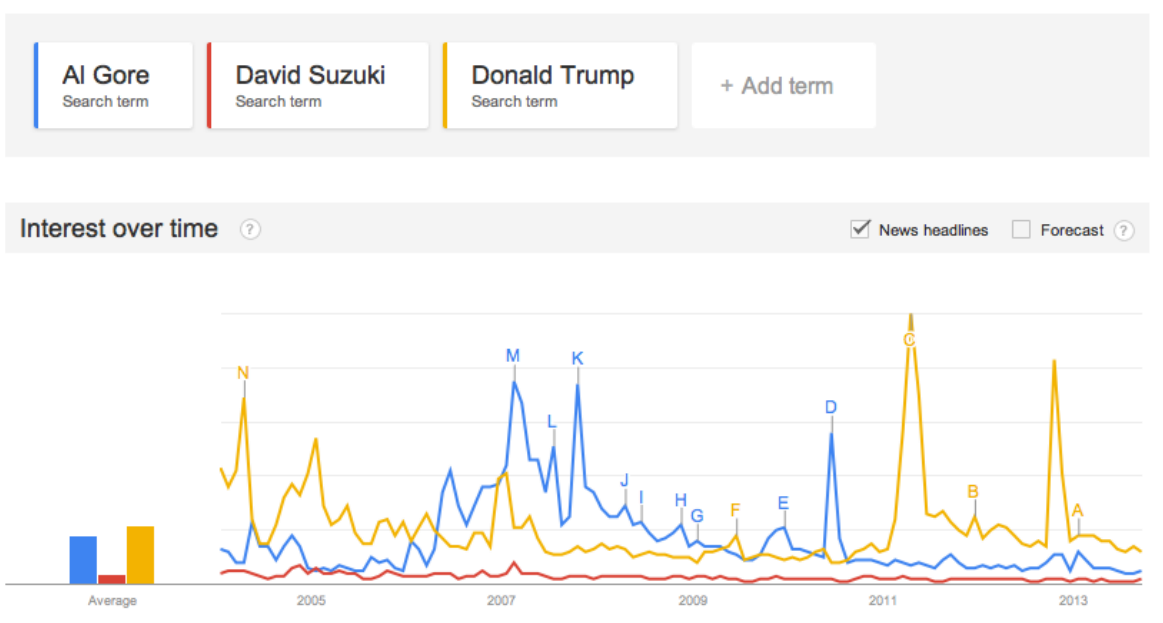

Figure 1. Google trends for Al Gore, David Suzuki, and Donald Trump

As Figure 2 indicates, in the grand scheme of branding and marketing, no one is even playing the same game as Justin Bieber. 


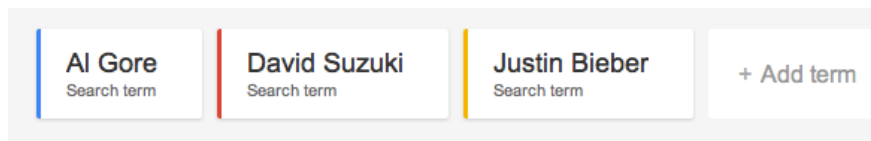

Interest over time

$\checkmark$ News headlines $\square$ Forecast

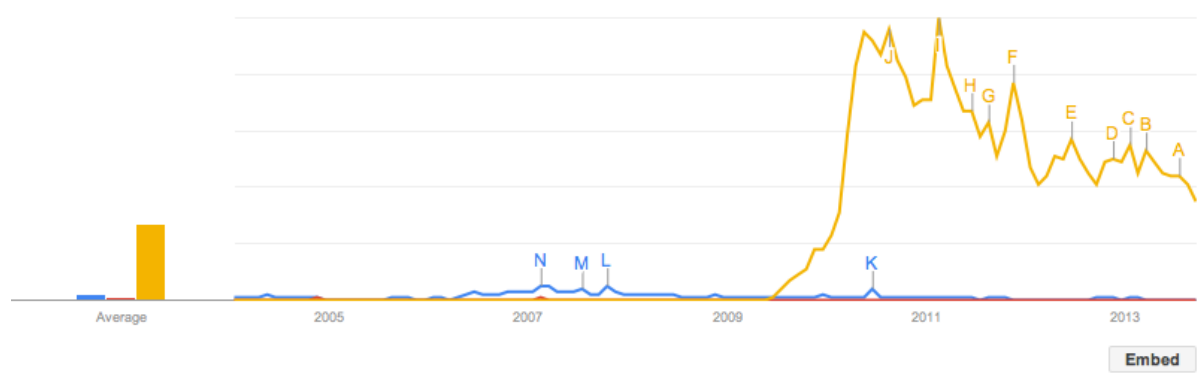

Figure 2. Google trends for Al Gore, David Suzuki, and Justin Bieber

In "Branding the Environment," Chis reiterates this message:

This movement needs an extreme image makeover. Marketing gurus tell me that all those depressing facts environmentalists throw into the ether might make us think, but they'll never get us to act... The trick is to replace the doom and gloom of environmentalism with positive, upbeat, motivating messages that request a specific action. (paras. $4 \& 8$ )

For his part, Professor of psychology at St. Thomas University in Fredericton, New Brunswick, Doug McKenzie-Mohr, seeks to address these shortcomings with his take on social marketing - community-based social marketing (CBSM). Adapting his understanding of social psychology and human behaviour, McKenzie-Mohr "systematically looks at desired behaviours, actual behaviours, and the reasons behind any dissonance" (p. 178). By identifying and removing barriers to compliance, educating the population under consideration, and asking for personal commitment to participate, new norms are established, norms from which individuals no longer feel comfortable straying. Taking advantage of the fact, Mackenzie-Mohr and his convert Ken Donnelly, Solid Waste Manager in Durham County, get 90 percent buy-in to municipal recycling and composting programs (p. 179). As Chris mentions "Peer pressure is a powerful thing, even among adults. No one wants to be the nail that sticks up. That is what makes CBSM a hopeful tool" (p. 182). By acknowledging and working with what is known from social psychology, CBSM holds great promise for more sustainable behaviour change. 
In addition, CBSM, and social psychology at its root, realize that if you can get small behavior changes in place, people "become more susceptible to bigger changes," the foot-in-the-door technique of marketing. Says Chris of this phenomenon: "Ask people to stop idling their engines unnecessarily, then ask them to keep their tires fully inflated for fuel efficiency, then to slow down to conserve fuel, then to carpool, then to take a bus or ride a bike" (p. 182). Because such new behaviours may at first result in cognitive dissonance, "a feeling of discomfort caused by the realization that one's behaviour is inconsistent with one's attitudes or that one holds two conflicting attitudes," (Aronson, 2013, p. 174) people are likely to reduce this discomfort by convincing themselves that they must be the kind of person who recycles, conserves fuel, and so on until they find themselves convinced that they are indeed the kind of person who cares deeply about the environment and climate change.

\section{Journalism - The Last Word?}

Can we count on journalists in their role as gatekeepers and agenda-setters to place environmental issues at the forefront of societal discourse? As it stands now, Chris is quite skeptical that mainstream media will take on such a role (p. 173). Environmental stories do not currently rank high on the list of publishable pieces, with editors and owners nervous to offend potential advertisers. Given the rapidly evolving, competitive media landscape, traditional media outlets are struggling, and many cater more to their advertisers and sensation-seeking consumers. "At the moment," writes Chris, "business, celebrity, and lifestyle stories are the most widely consumed and pull in the most advertising revenue, especially if sex and violence are involved" (p. 174). This being the case, most journalists hoping to guarantee themselves a pay-cheque understandably tailor their story pitches to the desires of the largely corporate-owned mainstream media who still control the message.

Chris presents Newfoundland-based Alison Dyer as a journalist who has balked this trend. As she currently writes for more than 30 newspapers and magazines across North America, her gamble seems to have paid off (p. 173). In addition, Alison "broadcasts on national radio, publishes photos online, and writes fiction and poetry which have been published in several literary journals" (p. 173). In all of these formats she takes "her environmental concerns and turns them into lively, factual emotional stories of people and their struggles for health and peace of mind" (p. 173). For instance, Alison's investigative work into arsenic-laced lumber resulted in the phasing out of this product in North America (p. 172). Working alongside other writers and lobbyists, she also helped ensure the crackdown on lawn pesticides in hundreds of municipalities across 
Canada (p. 172). At the same time, Alison has continued "writing celebratory pieces on nature. 'We need both,' she says, to inspire and inform” (p. 173).

Both Chris and Alison find much more environmental coverage, and hope, on social media and in blogs. In this vein, Eco-Innovators highlights thegreeninterview.com, a series of one-hour interviews hosted by Silver Donald Cameron. The Green Interview features some of "the world's greatest environmental thinkers - from Vandana Shiva to Farley Mowat" (p. 176). While such coverage on social media is exciting, Chris insists that it can't yet "compare in terms of exposure to what one television broadcast can do on a major network" (Interview, 2013). When mainstream media is increasingly concentrated in the hands of few - in New Brunswick, for instance, "the Irving family owns all the daily newspapers, save one French-language paper, and most of the weekly and community papers too" (p. 173) - Alison sees little possibility of change. In order for environmental and sustainability concerns to really crack major television and newspaper, Alison insists the impetus must come from a public who "must demand it from editors and publishers. We need better environmental reporting and storytelling in order for our great-grandchildren to have a world where they can live and thrive" (p. 174).

Storytelling is what Rod Dempsey, Charlottetown journalist, working with the Environmental Coalition of PEI, does best. He is currently collecting and posting online "fifty one-page stories about individuals taking action to reduce their environmental impact and carbon footprint" (p. 15). Much like Eco-Innovators itself, Dempsey's project details simple measures to enable us to make real, if small, changes: "turning lights off when we leave the room, brown bagging it for lunch to reduce fast-food trash, using a push mower, walking to work, and eating local food" (p. 15). While these behaviour changes are a great start, Rod realizes that our survival demands more and faster change.

Sharing success stories, spreading the word, gives Rod a sense of optimism. He is certain we will change our ways rather than accept the less pleasant alternative; that we will eventually shake off our materialism because if we continue business as usual, nature will restore the balance, and we'll be the ones to suffer. (p. 17)

This statement is an apt summary for Eco-Innovators as a whole: storytelling opens a dialogue about sustainability and strikes an emotional chord with readers. Through such narratives, Rod, and Chris himself, seem to make a conscious choice not to overwhelm readers with facts alone but to add heart to discussion. There is perhaps no better summary to this argument than that made by Chris himself in "Branding the Environment."

ECJ Volume 3, No. 1, 2013: The Voice of Change 
I'm glad environmentalists are armed with so many facts to confront a complex set of crises. I wish we all were. But the movement needs to learn the secret of great communication: Before you can engage their minds, you gotta touch their hearts. (para. 14)

Such is the strength of storytelling - and of Eco-Innovators: Sustainability in Atlantic Canada.

\section{Conclusion}

A disturbing headline in the Edmonton Sun from Tuesday, September 17, 2013, reads "Climate Change Hoax" (p. 15) in bold, capital letters, clearly emphasizing the concerns laid out in Eco-Innovators regarding the skepticism of mainstream media. In spite of this messaging, however, the biggest problem of the environmental movement is not that we need to convince people that climate change is happening. The majority is of this opinion. The challenge remains how to convince people to change their behaviours to match their attitudes, to change the dynamic from pure knowledge to action. EcoInnovators provides 35 different perspectives on how to accomplish this task. In addition to individual actions, such as more sustainable food, transportation, or housing options, Chris also provides us with suggestions for more systemic changes: from brilliant storytelling by both journalists such as Chris, to new business models such as Olivier Soaps, to environmental programming in public schools and universities, to communitybased social marketing and branding. When individuals, organizations, and businesses with greater reach can figure out the keys to behaviour change, when a critical mass is reached, the possibility for real and lasting change can emerge. Now and in this hypothetical future, the 35 stories in Eco-Innovators can serve as voices of change for how to live sustainably in our changing world and how to motivate others to do the same.

* Author: Tami Ambury is a second year student in the Bachelor of Communication Studies program at MacEwan University. She also has a Bachelor of Arts in Political Science and a Master of Arts in History from Simon Fraser University. Her thesis is entitled Continuity and Change in the Selection Process of the Ottoman Grand Vezirs, 1368-1789. Tami currently sits on the editorial board of Earth Common Journal and is a research assistant on projects dealing with disaster communication on social media. 


\section{References}

Aronson, E., Wilson, T.D., Fehr, B., \& Akert, R. (2013). Social Psychology (5 ${ }^{\text {th }}$ ed.). Toronto: Pearson.

Benjamin, C. (2010, January 28). Branding the Environment. The Coast. Retrieved from http:/ / www.thecoast.ca/halifax/branding-the-environment/Content?oid=1494903

Benjamin, C. (2011). Eco-Innovators: Sustainability in Atlantic Canada. Halifax, N.S.: Nimbus Publishing.

Environmental Change Institute. (2007, June). Climate Change \& Influential Spokespeople: a global Nielsen online survey. Oxford, England: Nielsen Company. Retrieved from www.eci.ox.ac.uk/publications/.../070709nielsen-celeb-report.pdf.

Levant, E. (2013, September 17). Climate Change Hoax. Edmonton Sun, p. 15.

PRME Principles for Responsible Management Education. (2013, September 23). PRiME time. Retrieved from http://www.unprme.org/index.php.

Rubin, J. (2009). Why Your World Is About To Get A Whole Lot Smaller: Oil and the End of Globalization. New York: Random House.

Vasil, A. (2007). Ecoholic: Your Guide to the Most Environmentally Friendly Information, Products and Services in Canada. Toronto: Random House of Canada. 